\title{
REFLECTIONS OF THEATRICAL ACTIVITIES IN LITHUANIAN LOCAL PERIODICAL PRESS UNDER GERMAN OCCUPATION 1941-1944
}

Summary. The article explores the reflection of Lithuanian theatrical activities in the local press during the World War II. As the number of articles shows, theatre was an important part of the dailies' content. The articles reveal that theatre activities were very important for the expansion of the Nazi culture. One can distinguish three general themes that the articles cover: promotion of Western theatre, especially German, promotion of Lithuanian repertoire and presentation of entertainment theatre. The latter can still be divided into entertainment for German soldiers and administration, and entertainment for Lithuanian audiences. The content of the articles reveals that journalists writing about theatre avoided Nazi propaganda clichés, such as hatred for Bolsheviks and Jews, but these clichés were nevertheless used by the representatives of theatre administrators.

Keywords: theatre, World War II, propaganda, Lithuania, small stage, Western theatre, Lithuanian theatre, Front theatre, press, media.

\section{INTRODUCTION}

This paper will examine the manner in which the local press during the period 1941-1945 reflected Lithuanian Theatre. Together with literature and radio, the press was considered the most important instrument of Nazi propaganda and was supervised by the Propaganda Department of the General Commissariat. ${ }^{1}$ The department permitted the publication of two Lithuanian dailies (I Laisvę (Ateitis), Naujoji Lietuva), five weeklies (Ūkininko patarejas, Tẻviškè, Žemaičiu žemé, Panevěžio balsas, Biržu žinios) and five journals (Savaité, Žiburèlis, Naujoji sodyba, Savitarpinès pagalbos žinios, Küryba). There were two dailies for German readers, Kauener Zeitung and Wilnaer Zeitung. Lithuanian theatre activities during war time were presented in the press as very engaging. I shall firstly discuss both the theoretical concept and the methodology relevant to the analysis of the topic. Thereafter, I will describe the statistical data related to the frequency of the articles and numbers of theatre spectators and performances with reference to the authors and content of the articles.
Scholarly discussion concerning the Nazi era and theatre may be observed in the recent research works of Alexander Hirt (2006), Anselm Heinrich (2007, 2017), and Gervin Strobl (2013). In Lithuania, the topic was also analysed by Linas Jašinauskas (2016), who published a study concerning the restraints on Lithuanian cultural life during the period of WWII, and Mantvydas Lugovojus (2016), who described it from an everyday life perspective. Vytautė Merkeliūnienė (2005, 2010, 2020), Rita Nomicaitè (2007), and Rita Aleknaitè-Bieliauskienè (2007) analysed the musical life and opera theatre of the war period; Vytautas Kubilius (2001) published a study addressing war literature; while Roberta Bartkute (2019), studied the entertainment environment of German soldiers. With regard to theatre, the research relates to biographies of some theatre personalities (Aleksaitè, 1998, Sakalauskas, 1999), and remains fragmentary.

The following article bridges this gap and is one of the first to provide a general overview of theatre activities in Lithuania during WWII, in an attempt to encourage a wider discussion of the topic. This analysis of press articles concerning theatre in 
Lithuania, makes possible some understanding of how theatre was organised and what it represented. However, for a more objective view, this investigation should be supplemented by a further research of other sources.

\section{THEORETICAL APPROACH AND METHODOLOGY OF THE RESEARCH}

Several theoretical perspectives may be employed in the analysis of historical evidence referring to the subject matter. One such perspective is that of cultural studies, which encourages an interdisciplinary approach to the analysed topic and critically confronts the methods and theories of the social sciences. ${ }^{2}$ The interdisciplinary approach can be applied to this specific analysis because theatre is seen and analysed in this paper through the perspective of the media. This means that the media, in this case, the press, serves as a social device that transforms information according to the perceived needs of society. Thus, information regarding theatre reflects not only cultural, artistic or qualitative aspects of the theatrical event (common to theatre research and historiography) but also its social impact. The interdisciplinary approach allows for the expansion of the field of historiographical theatre research and the updating of the research tools so that historical phenomena would be open to broader contexts and audiences. This article is an attempt to expand the field of theatre historiography and to embrace mechanisms that lead to more interpretative and communicative discourses common to the field of cultural studies.

The following research is based on an analysis of what was published in the Lithuanian press during the period 1941-1944. This press consists of the Lithuanian language dailies I Laisve (Towards Freedom), published in Kaunas from June 24, 1941 to December 31, 1942; Naujoji Lietuva (New Lithuania), published in Vilnius from June 29, 1941 to July 1, 1944; and Kauener Zeitung (Kaunas Newspaper), which was published in the German language from October 11, 1941 to July 7, 1944. The daily I Laisve was initiated by the Lithuanian Activist Front and represented the pro-governmental point of view until the end of 1942. At the beginning of
1943 it changed its direction and started campaigning against the Nazis. Therefore, it was replaced by a daily Ateitis, which existed until the middle of July 1944. The circulation of $I$ Laisve and lately Ateitis was approx. 90,000 copies per day, whereas the circulation of Naujoji Lietuva was 28,000 copies at the beginning of the period and 10,580 copies at the end of 1942. The number of copies of this daily diminished due to the shortage of paper. The dailies published in Kaunas consisted of 6 pages (Mondays-Fridays) and 8 pages on Saturdays; Naujoji Lietuva consisted of 4 pages (Tuesdays-Saturdays) and generally 6 pages on Sundays. According to Bražiūnas, the number of copies of Lithuanian language newspapers was insufficient because, for example, there was twice the demand for the newspaper Ateitis than the government could satisfy. ${ }^{3}$ This fact demonstrates that the local press was an important means of communication and that an important number of readers were interested in the content provided by these dailies. Articles and announcements published in the dailies allowed for an understanding of what was shown and what was said about theatre of that time. To describe the specificities of the war theatre repertoire and its reflection in the press, a chronological and comparative data analysis has been chosen.

\section{STATISTICAL DATA}

This chapter provides an overview of the data which concerns the numbers of theatres, performances and spectators, as well as the frequency of the press articles during the period under discussion.

Eleven theatres were active in Lithuania during the German occupation, funded either by governmental institutions or local municipalities. The German army entered Lithuania at the end of June 1941; the theatres began their new season three months later, in September. The first ones to reopen were Kaunas theatre of Opera, Drama and Ballet (The Grand Theatre of Kaunas), Vilnius City Theatre, Šiauliai Drama Theatre and Kaunas Youth Theatre, Vilnius Flying Theatre "Vaidila" commenced its season at the end of October and Theatre of Operetta was established in Kaunas at the beginning 
of November. A semi-professional theatre in Marijampole was started in December; ${ }^{4}$ the theatre in Panevėžys started its activities as well. An opera troupe was established at the beginning of 1942 at the Vilnius Filharmony. ${ }^{5}$ Semi-professional theatres were opened in Ukmerge in the middle of $1942,{ }^{6}$ as well as in Telšiai at the end of the same year. ${ }^{7}$ These theatres (Marijampolè, Panevėžys, Ukmergè and Telšiai) were funded by municipalities and promoted culture in the regions.

Independent entertainment and dance initiatives were also frequent: Danutè Nasvytytës group of modern dance performed a number of times in Kaunas, Vilnius and other cities, Marija Jakštanytës ballet studio performed in Vilnius, whereas entertainment artists (dancers, musicians, singers, coupletists, acrobats, magicians) were welcome on small stages in Kaunas ("Varietë") and in Vilnius ("Ali Baba"). There were two open air markets in Kaunas Oldtown (Fish market and Old Market) and one in Vilnius (Firewood market) where circus and entertainment artists performed during the summer season. These activities were dependent on ticket sales.

Alongside the above-mentioned activities, dedicated to all kinds of audiences, there were front theatres that served only Germans. Front theatres in the Third Reich were well-structured state-funded institutions serving not only German soldiers and army officials but also offering an attractive employment opportunity for artists of different nationalities. ${ }^{8}$ Shows were given in all the occupied territories and thus the morale of the German army was supposedly maintained. These theatres depended on the Ministry of Propaganda, which had its department at the Kaunas General Commissariat. ${ }^{9}$ Two such theatres were active in Vilnius (Soldaten-Theater I and Soldaten-Theater II), and one in Kaunas. They were served by wandering German actor troupes which stayed at one place from between several days to four weeks.

During the first Lithuanian Republic there existed only three state-funded theatres: Kaunas State Theatre (with Opera, Drama and Ballet) and its departments in Šiauliai and Klaipèda. Vilnius Flying theatre "Vaidila" was created in the 1930s under
Polish government. Vilnius State Drama Theatre was founded in 1939, after Lithuania regained its capital Vilnius from Poland in 1939 (from 1919 to 1939 Vilnius belonged to Poland), but it began its activities during the first Soviet occupation, in the autumn of 1940. Kaunas Children (Youth) Theatre and the Vilnius and Kaunas Jewish theatres were created in 1940 by the Soviets. However, Jewish theatres were closed as soon as the Germans arrived. Jews were driven into the ghettos where normal theatre activities were not possible anymore. ${ }^{10}$ If one compares the number of government-initiated theatres during the first Lithuanian Republic (1918-1940) with the number of theatres supported by German administration during WWII, it is apparent that the number of theatres almost tripled.

According to the information given to a journalist by the director of Kaunas Grand Theatre, the theatre gave approximately 11 performances per week. Two of the performances, operas and ballets, were given to Wehrmacht soldiers on Mondays and Thursdays. One or two closed performances were also given to Lithuanian soldiers, trade unions or schools. ${ }^{11}$ All performances, except for operas, were given in Lithuanian language. "Varietè" and "Ali Baba" theatres gave two performances per day and three performances per day during the weekend. ${ }^{12}$

The audience attendance numbers were announced in the press at the end of the seasons 1941-1942 and 1942-1943. According to the data provided by the director of Kaunas Grand Theatre, 181,000 spectators visited the theatre during the first seven months of the Nazi occupation ${ }^{13}$ and 301,000 spectators during the season 1942-1943. ${ }^{14}$ A comparison of this data with the audience numbers during the same time period in 1938 in this theatre indicates that attendance grew more than 30 per cent in both years. ${ }^{15}$ Vilnius City Theatre welcomed 74,694 spectators during the season $1941-1942^{16}$ and 60,806 spectators in the season $1942-1943 .{ }^{17}$ Šiauliai Theatre seated 85,240 spectators during the season $1941-1942^{18}$ and 59,526 spectators in the season $1942-1943^{19}$ (in comparison with 38,280 spectators during the Soviet occupation period 1940-1941). Kaunas Youth theatre had 54,346 spectators between 1941-1942 ${ }^{20}$. This significant 
augmentation of audience numbers was due to the fact that the German government insisted on lowering ticket prices, so that not only privileged classes but also people from lower classes and with lower income could have access to theatre. This system of cultural dissemination was supported by such organisations as Kraft durch Freude (Strength through Joy). Established by the Labour Front, this agency for programmed leisure subsidised different cultural events, including theatre performances. The agency cleverly "appealed to the petty bourgeois inclinations of the unpolitical workers" 21 and encouraged theatre performances for wider audiences which otherwise would never go to theatre. Together with trade unions, it educated lower class people, workers and employees, and facilitated their visits to cultural institutions. The lowering of ticket prices and consequently greater audience attendance created a ticket shortage. Numerous articles testify that it was difficult to obtain a ticket for any kind of performance in the above-mentioned theatres, as well as for performances on small stages, so that tickets needed to be bought on the black market. ${ }^{22}$ These data confirm that theatre was much more popular during WWII than it was during the first Lithuanian independence and during the first Soviet occupation (1940-1941). The composition of the audience changed - it was less cultivated and often did not know how to behave in a respectable institution, such as a theatre. ${ }^{23}$

The frequency of the articles concerning theatre demonstrates that culture was an important part of the press media content. The following table gives the number of the articles that were dedicated to theatre during 1942 and 1943. Two dailies are compared, the Kaunas daily $I$ Laisve, which was latterly replaced by Ateitis, and the Vilnius daily Naujoji Lietuva.

\begin{tabular}{|l|c|c|}
\hline \multirow{2}{*}{ Month } & $\begin{array}{l}\text { Title of the } \\
\text { newspaper/year }\end{array}$ & $\begin{array}{l}\text { Title of the } \\
\text { newspaper/year }\end{array}$ \\
\cline { 2 - 3 } & $\begin{array}{l}\text { I Laisvę/Ateitis } \\
\mathbf{1 9 4 2 / 1 9 4 3}\end{array}$ & $\begin{array}{l}\text { Naujoji Lietuva } \\
\mathbf{1 9 4 2 / 1 9 4 3}\end{array}$ \\
\hline January & $7 / 7$ & $8 / 13$ \\
\hline February & $6 / 11$ & $4 / 8$ \\
\hline March & $15 / 9$ & $7 / 14$ \\
\hline April & $11 / 8$ & $3 / 11$ \\
\hline May & $17 / 6$ & $6 / 15$ \\
\hline
\end{tabular}

\begin{tabular}{|l|l|l|}
\hline June & $12 / 16$ & $9 / 18$ \\
\hline July & $13 / 11$ & $2 / 14$ \\
\hline August & $6 / 5$ & $8 / 8$ \\
\hline September & $13 / 12$ & $12 / 14$ \\
\hline October & $8 / 17$ & $15 / 13$ \\
\hline November & $10 / 15$ & $12 / 15$ \\
\hline December & $15 / 11$ & $8 / 17$ \\
\hline
\end{tabular}

Table 1. Number of articles about theatre

As we see, the number of articles dedicated to theatre varies from 4 to 18 per month. The average number of articles in both dailies is 11 per month, or approximately 2 articles per week. These statistics do not include announcements of performances or events which appeared in the newspapers almost daily. Neither do they include articles on theatre in countries other than Lithuania. The data provided above indicate that there was intensive theatre activity which was in great demand. There were more active theatres and more audiences engaged during the Nazi occupation than during the First Lithuanian independence and the first Russian occupation.

\section{CONTENT ANALYSIS}

The following chapter will give an overview of the authors writing about theatre and the content of their articles. The press was one of the only remaining means whereby Lithuanianness could be defended, and the authors found themselves in the front-line of this defence. As the German government forbade almost all the publishing of Lithuanian literature, newspapers became the only place where authors could continue to express themselves. According to Kubilius, collaboration with the Nazi press and writing about culture was treated as one of the "most important forms of the self-defence of the nation". ${ }^{24}$ As almost all the newspapers and journals were axed, the number of authors writing in the dailies during that time multiplied. Among the authors writing about musical theatre or ballet one can find Jonas Kardelis, Vladas Jakubėnas (both emigrated from Lithuania in 1944), Konradas Kaveckas and an author of the younger generation Algimantas Kalinauskas, nicknamed St. Namigla (both continued to work in Lithuania after the war). All of them were multi-talented and 
not only wrote about theatre events but were also active musicians or administrators. Kardelis, for instance, was appointed for some time as Director of Vilnius Filharmony during the war, Kaveckas was a composer, a choir director and also Director of Vilnius Filharmony for some time, Kalinauskas was an active violinist and later became conductor of Vilnius symphonic orchestra, Jakubėnas was a composer and pianist. All of them attempted to contribute a professional overview of performances describing the structure of the piece and evaluating the performance of singers, dancers and musicians. The style of their articles was constructive and objective, they avoided criticising artists or evaluating performances in broader aesthetical perspectives that might cause problems with the censors.

Drama theatre activities were reviewed by Juozas Keliuotis, Juozas Žlabys-Žengè, and Bronys Raila (one of whose pen-names was Ant. Valkiniškis). These three authors were openly collaborating with the Nazis. Keliuotis was appointed by the Nazi government as head of the administration of art affairs, Žlabys-Žengè belonged to the Lithuanian Nationalist Party, and both were sent by the Soviets to Siberia after the war. Raila, one of the founders of the Lithuanian Activist Front, managed to escape in 1944 to the West. Although these authors were politically pro-active, their articles about theatre were neutral in tone and did not reveal any political opinions. More stylistically nuanced were articles by Pulgis Andriušis (real name Fulgencijus Andrusevičius) and Stasys Santvaras (real name Zaleckis): both of them left Lithuania for the West in 1944. Pulgis Andriušis' articles reveal the author's aspiration to engage the reader in a more direct discussion with the author. For instance, in his article "Moterys kovoja Kauno scenoje" ("Women struggling at the Kaunas Stage" ${ }^{25}$ he uses irony, and introduces into his article an imaginary interlocutor, a doctor, who criticises Lithuanian actresses playing French vaudeville. Not happy with the performance, the author directly addressed the director of the play, Stasys Pilka, and invited him not to be angry, but just to be braver in his creation. This personalised style can be also detected in his other articles, such as "Ittartinas posūkis" ("Suspicious Turn”), ${ }^{26}$
"Novelistas lipa i sceną" ("A Novelist is Going on Stage"). ${ }^{27}$ Although Santvaras, another author, was not an active journalist (he was first and foremost a playwright, poet, opera singer, and Director of Kaunas Youth Theatre for a while) and wrote only a few articles, his personal style may be detected while reading impressions about Estonian and Latvian Drama Theatres. ${ }^{28}$ The author describes not only the activities of the theatres but also what he had seen through the train window: broken bridges, burnt houses and cities in Latvia and Estonia. $\mathrm{He}$ talks about the deported or disappeared Latvian and Estonian artists, thus giving the reader an indirect impression of the atrocities brought by the war. This article was one of the rare instances where the connection between culture and war was directly drawn. In general, most of the articles remained either unsigned or simply initialled. Therefore, it is difficult to identify real authors. One can nevertheless observe a tendency to write about theatre performances from a positive perspective avoiding ideological or aesthetic debates. Mindful that the working conditions were difficult because of hunger and lack of means, authors avoided criticising actors and creative teams.

Alongside the descriptions of new performances, an important augmentation of articles dedicated to important theatre personalities may be observed. These were written on the occasions of anniversaries or death commemorations. According to Nomicaite, this was due to the fact that artists cherished one another much more now because of the recent Soviet deportations and exterminations. ${ }^{29}$ These articles provide a glimpse into a biography of a personality, overviews of creative work and style but again, the political stance of the described personality is not commented on.

The content of the analysed articles can be divided into four thematic topics. The first relates to the promotion of the Western theatre repertoire, with German repertoire as one of its most important pillars. The second concerns the attempt of Lithuanians to promote Lithuanianness and defend a culture which confronted the dangers of German intrusion. The third concerns small stage and entertainment programmes, conceived for both German 
and Lithuanian audiences. These three thematic topics offer an overview of the repertoire as it was revealed in the press. The fourth reveals the vocabulary which was used in theatre articles in order to confirm to one of the aims of Nazi propaganda - to spread hatred regarding Jews and Bolsheviks. ${ }^{30}$

\section{PROMOTION OF WESTERN THEATRE}

Theatre promotion was one of the main cultural tools utilised in disseminating Nazi propaganda in Germany and the newly occupied countries. As various testimonies demonstrate, the chief political figures - Adolph Hitler, Joseph Goebbels and Hermann Göring - were faithful admirers of theatre and wanted it to become one of the most important instruments of nation-building. ${ }^{31} \mathrm{New}$ theatre buildings were built in different German cities and access to them was facilitated by reducing ticket prices. ${ }^{32}$ Lithuania was no exception in this development.

As soon as the first season began, Lithuanians were invited to see performances which represented German culture at its best. One of the first performances was Richard Wagner's opera "Tannhäuser" presented in Kaunas Grand Theatre. ${ }^{33}$ This opera was followed by another piece by Wagner's, "Lohengrin". Both operas were known by the audience in Kaunas as they had been staged earlier, in 1926 (“Lohengrin”) and 1937 (“Tannhäuser”). Wagner represented the Romantic spirit and anti-Semitic views, therefore he was the best example of the culture that the Nazis were striving for. That is also why he was promoted by the local government. Another German opera offered to the Lithuanian audience was Eugene d'Albert's “Tiefland" ("Lowland"). Scottish-born d'Albert considered himself to be German and spent most of his life in that country. Most other opera and ballet performances consisted of the world classics, such as Giuseppe Verdi's operas "Traviata", "Rigoletto", "Aida", Giacomo Puccini's opera "Madame Butterfly", Charles Gounod's "Faust", Leo Delibes's ballet "Coppelia". It is evident that theatre indeed largely served as a platform for the most prominent Western European theatre works.

As there was a long tradition of operetta in Ger- many, the Nazi government took care to create an operetta theatre inside Kaunas Grand Theatre. This theatre was opened with Hitler's beloved piece, Franz Lehár's "The Merry Widow". It was followed by another operetta by the same author, "The Count of Luxembourg". Austrian composer's Franz von Suppe's "Light Cavalry" was also staged in Kaunas, as well as Johann Strauss' "Zigeunerbaron". However, operetta in Lithuania could not achieve the same level as opera or ballet because, according to the press, Lithuanian artists did not have the feeling of lightness and aristocracy which was necessary for the genre. ${ }^{34}$

In terms of drama theatre, firstly, emphasis was laid on the Nobel prize winner Gerhart Hauptmann. Hitler paid special attention to the celebration of Hauptmann's eightieth birthday in 1942 and proposed that the collected works of this author should be published in the whole country in spite of a shortage of paper. ${ }^{35}$ Lithuanian theatre paid tribute to the author by staging five of his plays in different theatres: "Before Sunrise", "Colleague Crampton", "Rose Bernd", "Dorothea Angermann" and "Hannele". Secondly, special attention was given to a repertoire which would have educative and entertainment purposes, therefore, such plays as Otto Ernst's "Flachsmann as Educator" or Heinrich von Kleist's "The Broken Jug" were staged. Ladislas Fodor, Otto Indigo and István Békeffy were Hungarian playwrights whose dramas were also on the lists of different theatres. A number of comedies were taken from the existing repertoires of the theatres, such as Flers and Caillavet's "Buridan's Ass", Henry de Regnier's "Lully the Musician" and similar works. These performances were not regarded as serious achievements but the press did not criticise them, explaining that the times were difficult and that theatres lacked the means for something better. There was only one article in which it was stated that most of the performances were too realistic and that they did not achieve the level of earlier Lithuanian theatre, where performances of Shakespeare were staged, or performances like "Šarūnas", the cult performance of Lithuanian author Vincas Kreve produced in 1929. ${ }^{36}$ The author demanded romantic, idealistic interpretations which would invite audiences to rise above everyday-life matters. Keeping that in mind, 
some theatres introduced plays which would deal with more complicated existential questions. Henrik Ibsen's "The Wild Duck" and "Nora” ("A Doll's House") were performed in Kaunas Grand Theatre and Vilnius City Theatre. "Nora" (director Romualdas Juknevičius) was considered to be the best performance of the period and was much discussed by different critics in the press, but such dramas were rare. The rest of the performances could not satisfy audiences with a more cultivated taste. On the other hand, the mediocrity of the repertoire was supported by Kraft durch Freude (Strength through Joy).

One of the particularities at the beginning of the period under discussion was that some of the opera or ballet performances were analysed by German journalists, in order that Lithuanian readers were exposed to an opinion other than that of Lithuanian journalists. Johannes Rowinski's articles about “Tannhäuser" and "Coppelia” were written in German and published in the daily I Laisve,$^{37}$ whereas Hans Rutz published his articles about "Tiefland" 38 and "Lohengrin" in the Kauener Zeitung. The article about "Lohengrin" was translated and presented in the above-mentioned Lithuanian daily. ${ }^{39}$ The articles praised Lithuanian singers and dancers and were presumed to encourage better mutual understanding between the nations. In general, opera was the most suitable field for the representation of the Third Reich in Lithuania. Being of international nature and speaking with the language of music, it could create an impression of unanimity; therefore, German officers were often guests at opera events in Kaunas and Vilnius. Operas were also broadcast on the radio. ${ }^{40}$ The dissemination of opera, ballet, operetta and various kinds of drama performances were meant to foster the feeling of community in Lithuania, and was part of the political rhetoric of the Nazis. ${ }^{41}$

\section{LITHUANIAN REPERTOIRE}

Alongside the Western theatre repertoire, Lithuanian plays formed an important part of the repertoire of public theatres. Over twenty-five Lithuanian plays were staged from 1941 to 1944 . Most of them were dedicated to adult audiences and dealt with the topics of modern society. However, the subject matter could be presented only from clearly defined perspectives which would not move away from the völkisch doctrine. This doctrine, based on German Romanticism, was designed to assist in creating a society which would draw its strength from its past, especially peasant culture. Lithuanian culture during the first independence tended to promote the ideas of Romanticism, therefore there was no contradiction between the Lithuanian and the German approach to culture and its aims. ${ }^{42}$ Plays with a strong romantic or educative profile were desirable and they could be found in the pre-war repertoire of Lithuanian theatre. Petras Vaičiūnas, Kazys Binkis, Sofija Kymantaitè Čiurlionienè, Vincas Krèvè, Antanas Vienuolis were all authors of the older generation whose artistic work was influenced by the trends of Romanticism. Theatres also featured plays of the new generation, which was represented by playwrights Vytautas Alantas, Stasys Santvaras, Juozas Grušas, Kazys Inčiūra, Vincas Adomėnas. Special attention was given to children's repertoire: Kaunas Youth Theatre and Vilnius "Vaidila" Theatre staged performances based on Lithuanian fairy tales. As the analysis of the articles about Lithuanian performances indicate, critics were positive about them because they revealed Lithuanian character from a positive perspective. Characters from bucolic and ethnographic milieus were distinctive in their didactic portrayal of a natural naivety. According to the press, this was what Lithuanian society needed, not those nihilistic characters that were common on stage before the war. ${ }^{43}$

In spite of the number of Lithuanian plays staged during the war time, Lithuanian cultural society was concerned that they were not enough. New collaborations were demanded between theatres and playwrights. Good royalties and big audiences were the reasons which had to motivate writers to work with theatres. ${ }^{44}$ A commission of Lithuanian dramaturgy was launched by the General Counsellor of Education in Vilnius at the beginning of $1943 .{ }^{45}$ This commission was composed of famous Lithuanian drama writers, university professors and theatre representatives. It was to play the role of a mediator who would encourage cooperation between playwrights 
and theatres, support young writers and help theatres to objectively evaluate new plays.

Lithuanian drama was also encouraged by the radio, which had launched a contest in February 1943. ${ }^{46}$ According to contest rules, authors could choose whatever topic or form they desired. The only condition was that the play would correspond to the demands of an audio play and would reflect national content according to propaganda directives. The contest was supported by the most important figures in German government in Lithuania, the General Commissar Theodor Adrian Von Renteln and the first General Counsel Petras Kubiliūnas. Both of them offered prizes from 250 to $1,000 \mathrm{RM}$ for the best plays.

National opera saw one Lithuanian creation during the war period. "Pagirenai", an opera of the famous composer Stasys Šimkus, premiered in the summer of 1942. The composer wanted to showcase the singing Lithuania of his youth, with lots of authentic Lithuanian folk songs ${ }^{47}$ and this was praised by the press. Lithuanian theatre still lacked national ballet performances. An article appeared in 1941 where the author urged Kaunas Grand Theatre to make a Lithuanian ballet, no matter the subject. It could be a fairy tale with Lithuanian gods or goddesses, or warriors and their beloved ones, or mothers and daughters. ${ }^{48}$ The first Lithuanian ballet finally performed in 1943. "Sužadètinë" (The Fiancée) composed by Juozas Pakalnis, depicted Lithuanian life in the mid nineteenth century, a time when there was strong national opposition to the Russian empire and serfdom. The performance was greeted by critics with enthusiasm. They praised Lithuanian dances and games which were perfectly integrated into the choreography of the performance. The critics rejoiced because the ballet corresponded to the striving of Lithuanian theatre to create performances which would be purely national in form and content. The ballet succeeded in meeting their expectations. ${ }^{49}$ Most of the authors tried to find ways to express Lithuanianness using ethnographic elements in plot, music, choreography and visual solutions. The press praised this, saying that "Lithuanian society had never had so many sentiments for Lithuanian art and culture before. It is a pleasure to work in such an atmosphere ..." ${ }^{50}$ As the analysis of the press articles shows, German authorities allowed Lithuanian theatres to continue to perform Lithuanian repertoire that was common during the first Lithuanian independence and was based on the ideas of Romanticism.

\section{SMALL STAGES}

Along with the performances on big stages, the Nazi government promoted small theatres with a repertoire based on sketches, couplets, songs, dances and circus show elements. This kind of theatre was more flexible, could be performed in venues which were not specially adapted for theatre and could meet the expectations of less-educated audiences. Even if the press from time to time reported on what was appearing on these small stages, it did not want to be associated with such a type of theatre activity because the quality of these shows was not befitting the standard expected by the readers of a newspaper like Naujoji Lietuva. ${ }^{51}$ It was different for Kauener Zeitung, which regularly reported on the performances and groups at the Soldaten-Theater. This is not surprising because it was the daily for the German-speaking inhabitants of Kaunas, especially the soldiers, officials, employees, shopkeepers and businessmen.

There were two sorts of audiences for small stage theatre. One was strictly German and consisted of soldiers and local administration. This particular group was served in two theatres in Vilnius (Soldaten-Theater I and Soldaten-Theater II) and one in Kaunas. All the performances shown in these theatres were played by German actors who were touring in the areas where German army was present. The daily Kauener Zeitung gave detailed descriptions of the actors and the programmes. These descriptions revealed that most of the performances served to amuse the audience. This type of "camp" theatre, or Fronttheater, was not a novelty. Governments in different countries used it for "boosting nationalist morale, for tying soldiers to the home front, for bringing vivid memories of the homes, loved ones and way of life they were seeking to protect".52 As the war advanced and there were 
not enough German soldiers on the Eastern Front, actions were taken to form Lithuanian soldier groups for the German army. These groups had to be served by the Frontheater formed from Lithuanian actors and singers. The first one was created in July 1943 and toured in places where Lithuanian soldiers were present.

Another sort of audience was local people for whom theatre needed to be a place of amusement and relaxation. This audience was invited to two special venues in Kaunas (the former People's House and the former Firemen's Hall), and one special venue in Vilnius (“Ali Baba” at 66, Didžioji Street). Šiauliai citizens could see such performances in the city theatre. Also, such performances were shown in two open markets in Kaunas and one in Vilnius during the warm season. The programmes were organised around personalities which could attract big spectator numbers. One such personality was a stand-up comic, Petras Biržys. With his pseudonym, Pupu dede (Uncle Bean), he created a label which attracted people in big cities as well as in small villages. At the beginning, his enterprise in Kaunas was called "Pupur dèdès pastogè" (The Shelter of Uncle Bean), later on he moved into a theatre called "Varietë". Many artists performed together with him: dancers, acrobats, magicians, singers. The programme had to be refreshed almost every two weeks in order to keep the audience's attention. Although the performances were supervised and censored by Nazi censors, Pupu dede managed to introduce anti-Nazi lines in his couplets, which led to him being arrested and spending some time in prison. ${ }^{53} \mathrm{~A}$ similar kind of theatre was opened in Vilnius almost a year later, at the end of 1942. It was called "Ali Baba" and presented mostly programmes for which knowledge of Lithuanian was not necessary, because the audience was composed largely of Polish and Russian locals who did not really understand Lithuanian. The theatre was reproached for this deficiency. ${ }^{54}$ Entertainment activities were organised not only by theatre people but also by such organisations as "Lietuvių studentų vartotojų bendrovè Studentai" (Association of Lithuanian Student Consumers), ${ }^{55}$ or "Poilsio ir gyvenimo džiaugsmas" (Joy of Leisure and Life). The latter was established by the trade unions which were active in Lithuania during the whole period of the Nazi occupation. Activities on the small stages were very intensive during the seasons of 1942 and 1943 but began diminishing at the end of 1943, as the Germans retreated at the Eastern Front. Performances continued at the SoldatenTheater until June 1944.

\section{HATRED OF BOLSHEVIKS AND JEWS}

Alongside the presentation of theatre repertoires and their content, alongside certain critical reflection concerning the quality of the performances, articles about theatre reveal the attempts of theatre people to avoid political language clichés which otherwise were very apparent in the texts of the dailies. One of the major Nazi propaganda themes was the hatred of Bolsheviks and Jews. Only a few articles evoke this theme and they relate to the speeches of the directors of the most important theatres, Kaunas Grand Theatre and Vilnius City Theatre. The speeches were arranged according to the rules laid down for the press by the Propaganda department of the General Commissariat. Compliance with the rules was supervised by the Propaganda agencies (Propaganda Staffel) of the cities. ${ }^{56}$

The first article, which corresponded to the demands of the new regime to fight Bolsheviks and Jews, appeared only in April 1942..$^{57}$ It was an interview with the Director of Kaunas Grand Theatre, Vladas Ivanauskas, giving a detailed overview of the relationship between theatre and the Bolshevik government. The article began with the personal story of Ivanauskas, who took over the direction of the theatre right at the beginning of the war, when he was liberated from jail, after he had been imprisoned by the Bolsheviks. The director described how the theatre looked during the Soviet regime: it was obliged to have a so-called "red board" for propaganda purposes and a wall newspaper for the same aim. He emphasised that the theatre managed not to allow any Jews to be selected for the committee of the theatre trade union and thus stressed that the theatre community resisted Bolsheviks. In order to demonstrate the hatred that the theatre community felt towards Bolsheviks, he revealed that the statues 
of Lenin and Stalin, which were installed in the theatre, were destroyed by theatre people on the first day of the war. The director continued to vilify Jews stating that Jewish opera singers were supposed to replace Lithuanian soloists during the performances which were planned in Moscow, which "fortunately" did not take place because of the outbreak of the war. Ivanauskas explained how he had to deal with the problems which were caused by the Bolsheviks who, for instance, damaged decorations and props. The theatre lacked artists and orchestra musicians, which was also a big problem. Ivanauskas stated that the theatre under the new government could finally get back to the repertoire of Lithuanian and Western plays which had been forbidden by the Bolsheviks.

Two months later Ivanauskas issued another press release, which again revealed the Director's effort to please the current government. He declared that no one any longer forced the theatre to make disgusting propaganda plays, that his theatre could choose amongst the best European plays and perform Lithuanian dramas, which would not be "profaned by a hatred and strange ideology". ${ }^{58}$ At the end of the article he praised the Wehrmacht and its Lithuanian command, which had performed important services for the theatre, such as organisation of transport for actors and decorations, and supplying fuel. He completed his praises with a sentence which affirmed that "the victory of German arms had thrown far away the plague which was created by Jews and which was cherished by Bolsheviks in our parents country". ${ }^{59}$ Special thanks were given at the very end of the article to the General Commissioner, to the Lithuanian Commandant, to the Commissioner of Kaunas and to the First General Counsel.

Ivanauskas was one of the few directors who spoke out so openly against Bolsheviks and Jews in the press. Vytautas Alantas, the director of Vilnius City Theatre, vilified the Bolshevik enemy only at the end of 1943, when the discourse against Bolsheviks became extremely widespread because of German losses at the Eastern Front and because of the possibility that Bolsheviks would re-emerge in Lithuania. Alantas made a declaration during a meeting of Vilnius intellectuals, where protest speeches against the Bolsheviks were delivered. He insisted that
Lithuanian culture was strongly related to Western culture, therefore it would never accept the Bolshevik culture. This culture, he said, denied art, making of it a terrible parody. It was a political instrument, a plague that would "destroy our nation and our culture without mercy". ${ }^{60} \mathrm{He}$ finished his speech by insisting that "we should never lose hope that the Bolshevik monster, which was born in Asia, will die finally thanks to the weapons of Western Europe". ${ }^{61}$ Circus director Vaclovas Černiauskas' announcement is the final example which illustrates the antiBolshevik discourse in the press. He was looking for circus artists for his newly established enterprise and published an announcement in which he emphasised that circus could not be active during the Bolshevik time, because "in this Jewish-Bolshevik slavery the activities of the circus were paralysed".62

The above-mentioned examples are the only ones identified where theatre people expressed themselves openly against Bolsheviks and Jews in the press. As we see, such speeches were delivered by the directors who were directly dependent on the Nazi administration. No such proclamations were found in the texts of theatre journalists or critics. This can be explained by the fact that Lithuanian journalists working for the dailies Naujoji Lietuva and I Laisve (Ateitis) tried to avoid using propaganda clichés in their articles and concentrated on the promotion of national culture, which was allowed by the Nazis, because they wanted "to maintain a favourable internal political atmosphere, to diminish opposition and resistance in the back of German army". ${ }^{63}$ This relative freedom of expression was tolerated during the first years of the German occupation, when the regime wanted to gain Lithuanian favour, however it began to be less acceptable following the defeats experienced by the German army in 1943. German authorities pushed the editors to obey propaganda rules and to censor the texts where opposition against Germans was expressed indirectly. ${ }^{64}$ However, not all of the editors obeyed. Rapolas Mackonis, the chief editor of Naujoji Lietuva, was sent to Stutthof concentration camp as a consequence of his disobeying of German authorities ${ }^{65}$ In spite of the restrictions, the dailies 
continued to inform their readers about the latest developments in culture and theatre.

\section{CONCLUSIONS}

The analysis reveals that there were more active theatres and more audiences engaged during the Nazi occupation than during the First Lithuanian independence and the first Russian occupation. The number and the frequency of the articles and announcements in Lithuanian dailies indicate that theatre was an important part of press media content. The overview of theatre activities in Lithuania through the lenses of the press reveals that repertoire based on Western theatre, German plays as the core of this repertoire was foregrounded. Reflection on performances, based on Lithuanian plays, was also an important part of the press content. Lithuanian journalists could write about Lithuanian performances because the content of the plays corresponded to the volkisch doctrine propagated by the Germans. Articles about small stage performances for Lithuanian audience were rare in comparison with articles which presented the official theatre. Theatre journalists avoided supporting the antiBolshevik and anti-Jewish discourse.

The statistical data relating to press articles concerning theatre and audience numbers, the introduction to the authors writing in the press and the overview of the content of the articles are one of the first attempts to present not only the reflections of theatrical activities in Lithuanian local periodical press but it is also one of the first general scholarly overviews of Lithuanian theatre during the WWII. This research is the basis for further analysis of the specific aspects of Lithuanian theatre during the German occupation and more generally of the role of culture during the WWII.

\section{References}

A. Gr. "Šiaulių teatras baigè sezonąa. Ateitis, 15 July 1943, 4.

Alv. "Ispūdžiai iš Ali Baba”. Naujoji Lietuva, 16 January $1943,4$.

“Announcement". I Laisvę, 13 March 1942, 5.
“Atnaujintos 'Lohengrino' operos atgarsiai”. I Laisvę, 31 December 1941, 4.

A. V. "Scenos menininkų dienos". Ateitis, 10 April 1943, 4.

Aliūnas, Z. "Jaunimo Teatro sezono balansas". I Laisvę, 18 July 1942, 4.

"Atidarytas Marijampolès dramos teatras". I Laisvę, 10 December 1941, 4.

Bražiūnas, Mantas. "Legalios spaudos ir valdžios santykis Lietuvoje vokiečiu okupacijos metais (1941-1944)". Žurnalistikos tyrimai 7 (2014): 204.

Bubnys, Arūnas. Vokiečių okupuota Lietuva (1941-1944). Vilnius: Lietuvos gyventojų genocido ir rezistencijos tyrimo centras (1998): 472.

Bulzgis, Stasys. Pupu dède. Šiauliai: Saulès delta, 1996, 41.

"Cirko artistų dèmesiui". I Laisvę, 17 April 1942, 5.

“Darbymetis Kauno D. Teatre”. I Laisvę, 7 April 1942, 6.

Dieckmann, Christoph. "Savivaldos politikos galimybès vokiečių okupuotoje Lietuvoje 1941-1944 metais". Lietuva Antrajame pasauliniame kare. Vilnius: Lietuvos gyventojų genocido ir rezistencijos tyrimo centras, Lietuvos istorijos institutas, 2007, 130.

Heinrich, Anselm. Theatre in Europe under German Occupation. London: Routledge, 2017, 2.

Hirt, Alexander. Die Heimat reicht der Front die Hand. Kulturelle Truppenbetreuung im zweiten Weltkrieg. PhD diss., Universität Goettingen, 2006, 222.

Jv. “Stasio Šimkaus 'Pagirènai' Kauno D. Teatre”. I Laisvę, 23 June 1942, 5.

Jakubėnas, Vl. "Mūsų operos jègos koncertuoja Wehrmachtui". I Laisvę, 2 May 1942, 5.

J. K. "Vilniaus dramos teatras baigè sezoną". I Laisvę, 1 July 1942, 2.

"Kai kurie kultūrinio gyvenimo rūpesčiai". Ateitis, 11 February 1943, 3.

Kardelis, J. “Nauja 'Sužadètinès' forma ir lietuviškieji jos šokiai”. Ateitis, 5 April 1944, 3, 4.

“Kas parašys geriausią radijo vaidinimą?” Ateitis, 5 February 1943, 6.

"Kauno D. Teatro naujojo sezono planai". I Laisvę, 15 August 1942, 4.

"Kauno teatro atidarymas". I Laisve, 13 September 1941, 5.

"Kauno Didžiojo teatro 1941-1942 m. sezono apžvalga". I Laisvę, 27 June 1942, 5.

Kèdainis, V. "Keli bruožai iš Kauno kultūrinio gyvenimo". Naujoji Lietuva, 13 May 1942, 2; ."Vilniaus teatrai". Ateitis, 16 January 1943, 4.

Kubilius, Vytautas. Neparklupdyta mūza: lietuviu literatūra vokietmečiu. Vilnius: Lietuviu literatūros ir tautosakos institutas, 2001, 219.

Namigla, St. "Operetès gastrolès". Naujoji Lietuva, 12 January 1943, 4.

Nomicaite,, Rita. "Straipsniai apie muziką lietuviškuose periodiniuose leidiniuose. $1940 \mathrm{~m}$. birželis - $1944 \mathrm{~m}$. vasara”. Menotyra 34(1) (2004): 36.

"Nūdieniai Kauno vaizdai". Ateitis, 10 February 1943, 4.

Lebovic, Sam. "A Breath from Home: Soldier Entertainment and the National Politics of Pop Culture during the World War II". Journal of Social History 47(2) (2013): 263, 265. https://doi.org/10.1093/jsh/sht082.

L. Nrb. "Kauno Didžiojo teatro darbai". Ateitis, 10 July 1943, 4 .

Lugovojus, Mantvydas. "Daily Life in Kaunas During the German Occupation (1941-1944): Housing, Food and 
Entertainment”. Kauno istorijos metraštis 16 (2016): 150. http://dx.doi.org/10.7220/2335-8734.16.6.

Mš. "Kultūrinius ịvykius prisimenant”. Naujoji Lietuva, 21 May 1944, 4.

P. Vr. “Publika!". Naujoji Lietuva, 17 April 1943, 4.

Pavis, Patrice. "Theatre Studies and Interdisciplinarity". Theatre Research International 26 (2) (2001): 154.

Pukelyte, Ina. "Reconstructing a Nomadic network: itineraries of Jewish actors during the first Lithuanian independence". Nordic theatre studies 27(1) (2015): 78-98. https://doi.org/10.7146/nts.v27i1.24241

Pulgis Andriušis. "Moterys kovoja Kauno scenoje”. Ateitis, 28 January 1943, 3. . "Itartinas posūkis". I Laisvę, 4 May 1942, 2. . "Novelistas lipa ì sceną". Ateitis, 19 February 1943, 3.

"Rašytojo V. Alanto kalba". Naujoji Lietuva, 30 November 1943, 2.

Rowinski, Johannes. "Die Tannhäuser - Aufführung in Kauen”. I Laisvę, 22 September 1941, 3; 6 October 1941, 3.

Santvaras, Stasys. "Estų ir latvių dramos teatrai". I Laisvę, 7 November 1942, 4.

Statistikos metraštis. 1939, 124.

"Sezoną uždarius". Naujoji Lietuva, 4 July 1943, 3.

Stankeras, Petras. "Vokietijos politika Antrojo pasaulinio karo metais". Lietuva Antrajame pasauliniame kare. Vilnius: Lietuvos gyventojų genocido ir rezistencijos tyrimo centras, 2007, 213.

Strobl, Gervin. "Cultural Continuities. Theatre and Political Power from the Holy Roman Empire to the Third Reich". The Journal of the Social History Society 10(3) (2013): 457. https://doi.org/10.2752/1478004 13 X13661166397346.

T. “Telšiuose atidarytas Žemaičių teatras". I Laisvę, 17 December 1942, 4.

“Ties Gulbių ežeru”. I Laisvę, 28 October 1941, 4.

"Ukmergeje kuriamas teatras". I Laisvę, 9 June 1942, 3.

"Vilnius sulauke operos". I Laisvę, 14 March 1942, 4.

Vingius, J. “Drama laimi”. I Laisvę, 11 July 1942, 4.

Welch, David. "Nazi Propaganda and the Volksgemeinschaft: Constructing a People's Community". Journal of Contemporary History 39(2) (2004): 217-226.

Žg. J. "Režisūros problema”. I Laisvę, 3 January 1942, 4.

\section{Notes}

1 Arūnas Bubnys, Vokiečiu okupuota Lietuva (1941-1944) (Vilnius: Lietuvos gyventojų genocido ir rezistencijos tyrimo centras, 1998), 472; Mantas Bražiūnas, "Legalios spaudos ir valdžios santykis Lietuvoje vokiečių okupacijos metais (1941-1944)", Žurnalistikos tyrimai 7 (2014), 204.

2 Patrice Pavis, "Theatre Studies and Interdisciplinarity”, Theatre Research International 26(2) (2001), 154.

3 Bražiūnas, 215.

4 "Atidarytas Marijampolès dramos teatras", t Laisvę (10 December 1941), 4.

5 "Vilnius sulaukè operos", I Laisvę (14 March 1942), 4.
6 "Ukmergèje kuriamas teatras", I Laisvę (9 June 1942), 3 .

7 T., "Telšiuose atidarytas Žemaičiu teatras", I Laisvę (17 December 1942), 4.

8 Alexander Hirt, Die Heimat reicht der Front die Hand. Kulturelle Truppenbetreuung im zweiten Weltkrieg ( $\mathrm{PhD}$ diss., Universität Goettingen, 2006), 222.

9 Bubnys, 454.

10 More about Jewish theatre in: Ina Pukelyte, "Reconstructing a Nomadic network: itineraries of Jewish actors during the first Lithuanian independence", Nordic theatre 27(1) studies (2015), 78-98, https://doi.org/10.7146/nts. v27i1.24241

11 "Darbymetis Kauno D. Teatre", I Laisvę (7 April 1942), 6.

12 Mantvydas Lugovojus, "Daily Life in Kaunas During the German Occupation (1941-1944): Housing, Food and Entertainment", Kauno istorijos metraštis 16 (2016), 150, http://dx.doi.org/10.7220/2335-8734.16.6.

13 "Darbymetis Kauno D. Teatre", 6.

14 L. Nrb., "Kauno Didžiojo teatro darbai", Ateitis (10 July 1943), 4.

15 Statistikos metraštis (1939): 124.

16 J. K., "Vilniaus dramos teatras baigè sezoną", I Laisvę (1 July 1942), 2.

17 "Sezoną uždarius", Naujoji Lietuva (4 July 1943), 3.

18 "Kauno D. Teatro naujojo sezono planai", I Laisve (15 August 1942), 4.

19 A. Gr., "Šiaulių teatras baigè sezoną", Ateitis (15 July 1943), 4.

20 Z. Aliūnas, "Jaunimo Teatro sezono balansas", ț Laisvę (18 July 1942), 4.

21 David Welch, "Nazi Propaganda and the Volksgemeinschaft: Constructing a People's Community," Journal of Contemporary History 39(2) (2004), 226.

22 V. Kèdainis, "Keli bruožai iš Kauno kultūrinio gyvenimo", Naujoji Lietuva (13 May 1942), 2; "Vilniaus teatrai", Ateitis (16 January1943), 4; A. V., "Scenos menininkų dienos", Ateitis (10 April 1943), 4.

23 "Nūdieniai Kauno vaizdai", Ateitis (10 February, 1943); P. Vr., “Publika!”, Naujoji Lietuva (17 April 1943), 4.

24 Vytautas Kubilius, Neparklupdyta mūza: lietuvių literatūra vokietmečiu (Vilnius: Lietuvių literatūros ir tautosakos institutas, 2001), 219.

25 Pulgis Andriušis, "Moterys kovoja Kauno scenoje", Ateitis (28 January 1943), 3.

26 Pulgis Andriušis, "Ittartinas posūkis", I Laisvę (4 May 1942), 2.

27 Pulgis Andriušis, "Novelistas lipa ị sceną", Ateitis (19 February 1943), 3.

28 Stasys Santvaras, "Estų ir latvių dramos teatrai", I Laisvę (7 November 1942), 4.

29 Rita Nomicaite,, "Straipsniai apie muziką lietuviškuose periodiniuose leidiniuose. $1940 \mathrm{~m}$. birželis-1944 m. vasara", Menotyra 34(1) (2004), 36.

30 Welch described four major themes defined by the Nazi propaganda: "1) appeal to national unity based upon the principle that the community is before the individual (Volksgemeinschaft); 2) the need for racial purity; 3 ) a hatred of enemies which increasingly centred on Jews and Bolsheviks; 4) charismatic leadership". David Welch, "Nazi Propaganda and the Volksgemeinschaft: Constructing a People's Community", Journal of Contemporary History 39(2) (2004), 217. 
31 Gervin Strobl, "Cultural Continuities. Theatre and Political Power from the Holy Roman Empire to the Third Reich", The Journal of the Social History Society 10 (3) (2013), 457, https://doi.org/10.2752/1478004 13 X13661166397346.

32 Anselm Heinrich, Theatre in Europe under German Occupation (London: Routledge, 2017), 2.

33 "Kauno teatro atidarymas", I Laisvę (13 September 1941), 5.

34 St. Namigla, "Operetès gastrolès", Naujoji Lietuva (12 January 1943), 4.

35 Strobl, 465.

36 J. Žg., "Režisūros problema", I Laisvę (3 January 1942), 4.

37 Johannes Rowinski, "Die Tannhäuser - Aufführung in Kauen", I Laisvę (22 September 1941), 3, (6 October 1941), 3.

38 Kauener Zeitung (10 December 1941), 3.

39 "Atnaujintos 'Lohengrino' operos atgarsiai", I Laisve (31 December 1941), 4.

40 Vl. Jakubènas, "Mūsų operos jègos koncertuoja Wehrmachtui”, I Laisvę (2 May 1942), 5.

41 Strobl, 461.

42 Christoph Dieckmann, "Savivaldos politikos galimybès vokiečiu okupuotoje Lietuvoje 1941-1944 metais", Lietuva Antrajame pasauliniame kare (Vilnius: Lietuvos gyventoju genocido ir rezistencijos tyrimo centras, Lietuvos istorijos institutas, 2007), 130.

43 J. Vingius, "Drama laimi", ț Laisvę (11 July 1942), 4.

44 J. Vingius, 4.

45 "Kai kurie kultūrinio gyvenimo rūpesčiai", Ateitis (11 February 1943), 3.

46 “Kas parašys geriausią radijo vaidinimą?", Ateitis (5 February 1943), 6.

47 Jv., "Stasio Šimkaus 'Pagirenai' Kauno D. Teatre", $t$ Laisve (23 June 1942), 5.

48 “Ties Gulbių ežeru”, I Laisvę (28 October 1941), 4.

49 J. Kardelis, "Nauja 'Sužadètinès' forma ir lietuviškieji jos šokiai”, Ateitis (5 April 1944), 3, 4.

50 Mš., "Kultūrinius ịvykius prisimenant", Naujoji Lietuva (21 May 1944), 4.
51 Alv., "İspūdžiai iš Ali Baba", Naujoji Lietuva (16 January 1943), 4 .

52 Sam Lebovic, "A Breath from Home: Soldier Entertainment and the National Politics of Pop Culture during the World War II", Journal of Social History 47(2) (2013), 263, 265, https://doi.org/10.1093/jsh/sht082.

53 Stasys Bulzgis, Pupu dèdè (Šiauliai: Saulès delta, 1996), 41.

54 "İspūdžiai iš Ali Baba", 4.

55 “Announcement", t Laisvę (13 March 1942), 5.

56 Although cultural activities were controlled and censored (by the Cultural Department of General Commissariat, which appointed referents of cultural affairs in city and regional commissariats), cultural institutions continued to work as they did before the outbreak of the war, because Germans considered them less important than economic ones, such as agriculture, transport and industry (Petras Stankeras, "Vokietijos politika Antrojo pasaulinio karo metais," Lietuva antrajame pasauliniame kare. Vilnius: Lietuvos gyventoju genocido ir rezistencijos tyrimo centras (2007): 213, Bubnys, 458, 499). One should mention that German control over Lithuanian theatres was less important than the one that was imposed on educational institutions, especially universities. The latter had to close in 1943 due to government dissatisfaction with regard to the fact that the universities prevented the creation of a Lithuanian SS (Schutzstaffel) unit. (Bražiūnas, 203-204).

57 "Darbymetis Kauno D. Teatre", 6.

58 "Kauno Didžiojo teatro 1941-1942 m. sezono apžvalga", I Laisvę (27 June 1942), 5.

59 "Kauno Didžiojo teatro 1941-1942 m. sezono apžvalga", 5 .

60 "Rašytojo V. Alanto kalba", Naujoji Lietuva (30 November 1943), 2.

61 "Rašytojo V. Alanto kalba", 2.

62 "Cirko artistų dèmesiui", I Laisvę (17 April 1942), 5.

63 Bražiūnas, 198

64 Ibid., 209.

65 Ibid., 211.

Ina PUKELYTE்

Vytautas Magnus University, Kaunas, Lithuania

\section{TEATRINĖS VEIKLOS ATSPINDŽIAI LIETUVOS VIETINĖJE PERIODINĖJE SPAUDOJE VOKIEČIU OKUPACIJOS METU, 1941-1944 M.}

\section{Santrauka}

Straipsnyje nagrinejjami Lietuvos teatrų veiklos atspindžiai vietinejje žiniasklaidoje Antrojo pasaulinio karo metais. Kaip rodo straipsnių skaičius, teatras buvo svarbi žiniasklaidos turinio, nacių kultūros dalis. Galima skirti tris pagrindines temas: Vakarų, ypač vokiečių teatro, sklaida, lietuviško repertuaro sklaida ir pramoginio teatro pristatymas. Pastarąji dar galima skirti ị pramoginị teatrą, skirtą vokiečių kariams ir administracijai, bei teatrą, skirtą 
lietuviškai auditorijai. Kaip rodo straipsnių turinys, apie teatrą rašantys žurnalistai vengè nacių propagandinių klišių, tokių kaip bolševikų ir žydų neapykanta, tačiau jų neišvengė spaudoje pasisakantys teatrų administratoriai.

Reikšminiai žodžiai: teatras, Antrasis pasaulinis karas, propaganda, Lietuva, mažoji scena, Vakarų teatras, Lietuvos teatras, Fronto teatras, spauda, žiniasklaida.

\section{Ina PUKELYTĖ}

PhD Ina Pukelyte is Associate Professor at the Theatre Studies Department of the University of Vytautas Magnus (Kaunas, Lithuania). She is a member of the International Federation of Theatre Research (IFTR/ FIRT) and is a former Head of Kaunas State Drama Theatre. Her research interests are Lithuanian theatre history, cultural policies and management. Her monograph Žydu teatras tarpukario Lietuvoje (Jewish Theatre in Lithuania in the Period Between the Two World Wars) was published in 2017. E-mail: ina.pukelyte@vdu.lt 